\title{
Eric Wolf: A semiotic exploration of power
}

\author{
Irene Portis-Winner \\ Massachusetts College of Art \\ 621 Huntington Avenue, Boston, MA 02115, USA \\ e-mail: tgipwinner@comcast.net
}

\begin{abstract}
This paper discusses Eric Wolf's (1923-1999) analysis of power in his last monograph, Anthropology (Wolf 1964) and last book Envisioning Power (Wolf 1999). In Anthropology, Wolf (1964: 96) wrote that the "anthropological point of vantage is that of a world culture, struggling to be born." What is worth studying is human experience in all its variability and complexity. His aim was to set the framework bridging the humanities with anthropology. He never gave up this quest, only expanding it. In the new introduction to his 1964 monograph, thirty years later, he commented that such a synthesis had not occurred. Rather there were growing schisms in the field. In the preface to Envisioning Power, he held that human sciences were unable or unwilling to come to grips with how cultural configurations intertwine with considerations of power. In 1990 he had addressed the American Anthropological Society, holding that anthropologists favored a view of culture without power, while other social sciences have advanced a concept of ideology without culture. He wrote that his aim in his last book was to explore the connection of ideas and power observed in streams of behavior and recorded texts. Since minds interpose a selective screen between the organism and environment, ideas have content and functions that help bring people together or divide them. While ideas compose the entire range of mental constructs, Wolf understands ideology as configurations or unified schemes to underwrite or manifest power. Power is, according to Wolf, an aspect of all relations among people. Within this framework Wolf analyzes three cases, the Kwakiutl, the Aztecs, and Nazi Germany. The comparisons are very revealing, both the wide differences and similarities in power configurations and in the role of imagination.
\end{abstract}


In my first paper about Eric Wolf (1923-1999), entitled "Eric Wolf: the crosser of boundaries" (Portis-Winner 2002a) I wrote that I discerned three streams in Wolf's thinking. To recapitulate, they were: (1) Wolf the sensitive poet. The exemplar was Sons of the Shaking Earth, 1959, which was the focus of my discussion. (2) Wolf the economic and political revolutionary anthropologist who founded peasant studies and abolished forever the notion of the static, ahistorical, unchanging, isolated groups composed of closed structures, whether tribe or peasant village. His own field work extended from Mexico to European peasants, a major topic was peasant history ironically entitled Europe and the People Without History (1982). The role of symbolism so fundamental to his early work in Sons of the Shaking Earth was not ignored in his later work, note his study of Christmas symbolism entitled "Santa Claus: Notes on a collective representation" (1964). Finally, (3) Wolf the theoretician and philosopher as well as the scientist who grappled with the notion of power and tentatively explored semiotic concepts in this endeavor, which is the subject of this discussion. While all these streams reverberate in all Wolf's works none were so ambitious as the question of power. In fact what is power? In what way is it a factor in control of others? In what sense does something like power ubiquitously permeate all human societies? Does it have any universal properties and what are its forms? This is the main theme of Wolf's last monograph, Envisioning Power, which I discuss in this article. ${ }^{1}$

This is an exploration barely depicted by anthropologists though particular agents and signs having kinds of power or social control are described in many ethnic studies. It has been left to European philosophers from Nietzsche and onward, to Marx and to French philosophers critiquing culture and society primarily in their contemporary forms, to discuss the universal pertinence of power variously manifested. Anthropologists' romantic search for utopian equalitarian societies has long been abandoned. But they have not dealt with the issue of power in the broad and comparative sense as has Wolf.

Indeed the response to the ubiquitous and pivotal penchant for transformation and hidden manifestations of power in our era is overwhelmed by the postmodern collapse when such potential universal

Portions of this paper were delivered at the International Semiotics Association Meetings, Lyon, France, July 2004. 
problems are abandoned for subjectivism, reductionism and deconstruction. Or power is reduced and simplified as special cases related to standard categories such as ecology, calories, myths and elements of the relatively static social structure.

By gaining a perspective on this general puzzle I look briefly at two French thinkers, Pierre Bourdieu and Michel Foucault, who may be thought of as philosophers and theoreticians of the grand concepts of power in culture and society. Their concern has been essentially with complex societies but not with specific case histories of whole cultures, although Foucault, for example, has considered modern institutions such as prisons and hospitals.

Turning to Bourdieu, a part of his theory of practice, meaning all symbolic activities, is the concept of "symbolic power [...] based on diverse forms of capital which are not reducible to economic capital" (Bourdieu 1993: 60). This position involves Bourdieu's concept of "cultural field" which is characterized as a "radical conceptualization" which supposes an "analysis of the position of the field with the broader field of power" (Bourdieu 1993: 9). His primary examples are literary, following Jakobson's and Tynjanov's concept of literary system (Bourdieu 1993: 10), although misunderstanding Jakobson's major works, since Bourdieu holds Jakobson's position, not true of his major works, in so far as it remains formalism (Bourdieu 1993: 9). Bourdieu praises Bakhtin, who in thinking of literature, holds it cannot be understood without the social context (Bourdieu 1993: 13). Of course Bakhtin did not limit his examples to literature, omitting social context, for example his famous study of the carnival. Bourdieu notes: "the degree of autonomy of a certain field is measured by its ability to reject external determinants and obey only the specific logic of the field" (Bourdieu 1993). Bourdieu's method "is to incorporate three levels of social reality": (1) the position of any cultural field within the "field of power"; (2) the structure of the field including any relevant agents; and (3) the genesis of the producers' habitus, which means the structured dispositions that generate practice (Bourdieu 1993: 1, 14).

I cannot in this short paper discuss Bourdieu and power further except to say that this is not the path of static structuralism or deconstruction and is in fact closer to the semiotics of the Prague school, the Tartu-Moscow school and particularly Lotman and also Bakhtin. 
I turn now to Foucault, another French thinker grappling with the issue of power. In a volume edited by Dreyfus and Rabinow (1982) entitled Michel Foucault: Beyond Structuralism and Hermeneutics, the editors assert that Foucault "is able to explain the logic of structuralism's claim to be an objective science and also the apparent validity of the hermeneutic counter-claim that the human sciences can only legitimately proceed by understanding the deepest meaning of the subject and his tradition" (Dreyfus, Rabinow 1982: xii). According to the editors, his method of interpretive analytics shows how human beings become the sort of "objects and subjects hermeneutics and structuralism discover and analyze" (Dreyfus, Rabinow 1982: xii). For Foucault totalizing is "bio-technical power" meaning ordering of all realms under the guise of improving the welfare of the individual and the population, which is simply a strategy to increase power and order (Dreyfus, Rabinow 1982: xxv). Foucault says he is writing a history of the present. He adopts the term "dechiffrement" where social practices have a meaning radically different from that available to the actors, suggesting Lévi-Strauss's disguised meanings.

The final chapter of this book is devoted to Foucault's conception of "Truth and power" (Dreyfus, Rabinow 1982: 184-226), which involves rituals of power and bio-power. Bio-power links the political technologies of the body, the discourses of human sciences and the structure of domination over the last 200 years. Here we note that power is not context free, not ahistorical, not an objective description. Power is not a formal theory. Rather it is a cluster of relations, which are mobile. Power is the operations of the political technologies throughout the social body, through political rituals of power that set up non- egalitarian asymmetrical relations, but power is not restricted to political relations. It is multidirectional and "operating from the top down and from the bottom up" (Dreyfus, Rabinow 1982: 185), and power and institutions are not identical. When these technologies are localized within specific institutions, bio-power takes off. Power is exercised upon the dominant as well as the dominated.

Examples are schools, hospitals and prisons. In sharp remarks concerning power, the editors write that for Foucault, "The spread of normalization operates through the creation of abnormalities which it then must treat and reform. Bio-power is spread under the banner of making people healthy and protecting them. Then if it fails it justifies more of the same" (Dreyfus, Rabinow 1982: 196). A political problem 
is recast into the language of science and becomes transformed into a technical problem. For example, bio-power establishes how welfare institutions work and not what they mean or what they do (Dreyfus, Rabinow 1982: 196). Foucault's account of normalizing science is similar to Kuhn's account of how sciences work (Dreyfus, Rabinow 1982: 197). Normalizing technologies preserve an increasingly differentiated set of anomalies and normalizing society becomes a powerful form of domination (Dreyfus, Rabinow 1982: 198).

As the editors tell us, Foucault calls for an interpretive analysis asking why these practices work. Calling on history and knowledge to unveil the truth, means that to understand the cultural practices is to "grapple with the history of the present" (Dreyfus, Rabinow 1982: 204). Foucault explains that he wants to understand the different modes in culture, which transforms people into subjects. The worst diseases of power are fascism and Stalinism. He outlines three types of struggles: (1) against forms of domination, ethnic social and religious; (2) against exploitation; and (3) struggles against forms of subjectivity and submission (Dreyfus, Rabinow 1982: 212). Language is involved in all these forms of power. Systems of communication, that is language as a system of signs may be imbued with power relations. Over and above purely: objective information, language and nonverbal communication implicates power in the following ways: (1) the tying of the message with power that consists of obligatory tasks of all kinds including nonverbal gestures, etc. and (2) finalized activities thus modifying the field of information between partners, producing effects of power (Dreyfus, Rabinow 1982: 218).

Turning to the nature of power, it exists only when it is put into action where actions modify others. "Power and freedom's refusal to submit cannot be separated" (Foucault 1983: 221). "Power relations are rooted deep in the social nexus" (Foucault 1983: 226) and must be analyzed from different perspectives. "A society without power relations can only be an abstraction" (Foucault 1983: 223). This and its forms and objective differentiations are imbued in the social structure, how it is institutionalized etc. "Power relations are rooted in a system of social networks" (Foucault 1983: 222) leading to the conclusion that domination is a central phenomenon in the history of societies, taking universalizing form and locking together power with relations of strategy and the results proceeding from their interaction. 
I turn to Eric Wolf's final quest and I stress that he was independent enough to attack the problem of the relation of power and ideas in culture, seeing power as a relational concept that has many possible forms, and is ubiquitous, as was also held by Foucault and Bourdieu, but Wolf added another dimension, that is, to explore and compare how power is grounded in specific culture forms exemplified by three case studies, namely the Kwakiutl, the Aztecs and National Socialist Germany. Thus, the relation of power to specific cultural configurations and ideas and the question of its general qualities constitute his quest.

Before discussing Wolf's last monograph and second to last book, Envisioning Power: Ideologies of Dominance and Crises (1999), I look at an earlier publication of Wolf in which his comments are I think emblematic of this scholar. After extensive fieldwork and theoretical excursions into complex societies, he was asked by the Council of the Humanities of Princeton University to contribute a volume on anthropology, which appeared in 1964 (Wolf 1964). In that study he emphasized "anthropology's role in bridging science and the humanities, bringing a multidimensional understanding of what it is to be human: the most scientific of the humanities and the most humanistic of the sciences" (Wolf 2001: 11). He wrote that he hoped that the interdisciplinary character of anthropology would give rise to a new synthesis. However, ten year later when writing a new introduction, he noted that such a synthesis had not occurred (Wolf 2001: 11), and even though in his last monograph he was still searching, he reached some stimulating hypotheses and conclusions which interrelate power laden ideas, ideology and imaginative worlds, which beg for deeper and more extensive investigation.

The knot that he wants to deconstruct and reconstruct is imaged in the preface of his final monograph where he argued that the humane sciences have "not come to grips with how social relations and cultural configurations intertwine with considerations of power. If anthropologists have favored a view of culture without power, other social analysts have advanced a concept of 'ideology' without culture" (Wolf 1999: ix).

Thus he wanted "to explore the connection between ideas and power" (Wolf 1999: 1). Power not being an abstract theory but a relational term "demands finding out ways to define the relations of power that are played out in social arrangements and cultural 
configurations and trace out the possible ways in which these relations of power implicate ideas" (Wolf 1999: 3).

The theoretical aspect of the discussion that follows in certain respects recalls Bourdieu and Foucault, but these writers did not undertake case studies in the anthropological sense in order to examine power in culture, although Foucault considered certain institutions in modern society such as hospitals and prisons, etc. Of course neither were obliged to use the anthropological method but my point is that Wolf alone trod the double path, megatheory and also its applications in its various forms in three very different societies separated in time and space, the cultures of which differed in complexity, their economies ranging from hunting and fishing to cultivators to modern industrialism. Finally Wolf reached out to ask how to apply Peircian semiotics to an underlying fundamental issue which seemed to fall through the cracks of anthropological studies, that is the question of meaning and how meaning is communicated, and how to detect elements of power in modes of communication. Even in Wolf's earliest book, Sons of the Shaking Earth (1959) there lurked this quest in the highly metaphoric and mythological study of the history of the Middle American Indians and the rise of the Aztecs.

In our discussion of Wolf's last monograph, I pay particular importance to his basic theme, "Ideas, Power and Communication" as well as the section entitled "Contested Concepts". Like Bourdieu and Foucault, Wolf distanced himself from the simplified view of ideas as mere reflections of the external world. Rather, minds interpose a selective screen between the organism and the environment. Indeed, mental constructions have content and functions. They have an important role in the play of power, resonating with Peirce's signs (the world is profuse with signs). Ideas for Wolf cover the entire range of mental constructs, while ideologies are specific schemes to underwrite power. Wolf's questions are how do ideas become concentrated into ideologies, and how is power understood as an aspect of all group relations?

Wolf (1999: 5) distinguished four ways in which power is woven into social relations: (1) power of potency characterized by a particular individual; (2) the analysis of an ego to impose its will on social action upon an other; (3) tactical or organizational power, where individuals circumscribe the actions of others in tactical or organizational power; (4) structural power, if powerful enough, that 
organizes the settings and specifies the direction and distribution of energy flow. Wolf compares this Marxist view of structural power to Foucault's "governance" to meaning "the exercise of 'action upon action"” (Wolf 1999: 5, cit. Foucault 1984: 427-428). But while Foucault was referring to structural relations that govern consciousness, Marx was thinking of class economic forces. Essentially I believe Wolf was attempting to combine or relate economic power with power over consciousness.

In a most important discussion, Wolf explores how ideas are a form of communication. He underlines the many modes of meaning that ideas embody. This is a much neglected area in anthropological studies where meanings are often reduced to locations, techniques, and other cognitive formal qualities and overlooked are verbal and nonverbal vehicles that are a part of communication and are potentially polysemic and poly-functional, subjective and metaphoric including ritual dress, culinary codes, codes of appropriate behavior, etc. But they must be decoded, as we know so well from Lévi-Strauss. These codes are not fixed. They vary with social contexts. Yet their dynamics have not been Lévi-Strauss's abiding interest even though they were implied in his depiction of the sad state of particular South American tribes. For Wolf, the dynamic changeability of codes, including the many nuances of meaning over and above the cognitive ones was fundamental — issues not limited by the static map of Saussure. Indeed, how codes are interpreted varies according to the domains they address — such as economic, political and languages, religion, etc. It also varies according to the characteristics of the sender, which involve different accesses to power. Their decoding depends on the choice of interpretants strained through the mind of the receiver. But neither encoding nor decoding are entirely arbitrary since at some level signs maintain some relation to the object signified, as Peirce has held. Thus "power equalities or differentials are at work in defining who can address whom from what symmetrical or asymmetrical positions. The grid formed by these rankings and positions in turn sets up the contexts for how things are said and performed and codifies how they are to be understood" (Wolf 1999: 7). Accordingly there is a tension between adhering to the formal properties of codes and fostering their variability. Wolf stresses the social and public quality of reproducing or modifying codes. While one cannot deny that inventing an isolated language by a single 
individual will not be understood, we cannot overlook the aesthetic realm of creativity where object of invented messages may eventually be understood by some sectors.

Returning to the primary issue of power for Wolf, he holds that "ideas [...] are often monopolized by power groups" (Wolf 1999: 7). Wolf criticizes linguistic and semiotics that do not address what the communicative act is about (Wolf 1999: 8) but this could hardly apply to the Prague or Tartu-Moscow school. But it is true that the Saussurian code accounts only for denotative meaning and is thus inadequate. However, Geertz's "Cock Fight" tells in symbolic terms much about the entire culture as does that of Victor Turner's study of the Ndembu and others. Wolf does accept Bourdieu's habitus which shows how people "acquire durable and transposable dispositions" conveyed by the institutional landscape of social settings. Such dispositions become symbolic systems that can become instruments of domination (Bourdieu 1992: 115-139; Wolf 1999: 10).

The linkage between ideas and power are the theme of the three case studies, the Kwatkiutl, the Aztecs of the 15th and 16th century, and Germans who peopled the Third Reich (Wolf 1999: 10). In discussing the dialectics and dynamic of language as oppose to Saussure, Wolf turns to Bakhtin who held that signs and their accents vary with social categories such as gender, occupation, status, and different interpretations of traditions. Such multi accentualities could turn communication into an "arena of struggle" (Voloshinov 1986: 23; Wolf 1999: 53).

Wolf is also attracted to Peirce's infinite regression, an open construct that permits the widest kinds of interpretations. For Peirce, the interpretant as well as the sign being interpreted must, as I have noted, have some relation to the object, whether it is by convention, in Peirce's terms symbolic, which some Saussurians call arbitrary, or by indexicality or contiguity with the object whether in the present or displaced by time or space, or by similarity or iconicity. All signs that are fully developed participate in all these levels although one level may dominate another. While Peirce did not consider culture as such, his concept of habits was close to that of culture and his many pithy examples of signs signifying the dynamics of context include the hot stove, where a child would interpret the hot stove differently than the knowing adult, and the Alps that may be interpreted as signs of danger or beauty depending on the perceiver. For Wolf, Peirce's interpretants 
all have different priorities and degrees of power (Wolf 1999: 55) which is not inconsistent with the Peircian world of signs.

I must limit myself to a few remarks bearing upon Wolf's case studies. The Kwakiutl story is an epic of transnationalism and imperialism and their ambivalent effects. Wolf sees the story of the Kwakiutl as an outstanding drama, which calls forth the unraveling of the connections of power and ideas, and reveals the effects upon the weaker society. There may be few transnational societies such as the Kwakiutl that utilizes such varied and perfuse symbolic signs in myriad types which bear complex meanings. Wolf writes that the Kwakiutl compose "a salient case explicating particular links between power and ideas" (Wolf 1999: 70). He traces the devastating years of contact and conflict between the Kwakiutl and the British forces, including laws of British Columbia and Canada restricting fishing and hunting reserves and making illegal potlaching and winter dancing in 1888. As we know and as Wolf (1999: 82) describes it, "the sociopolitics of rank hierarchy, descent and succession were intertwined with transfers of ceremonial titles and privileges" of marriages and with ritual, their control of rituals, myth, histories and emblematic art, much, has been preserved in memories of the past. Artistic traditions were remembered and found new outlets in markets. In 1951 the potlach was legalized and in 1979 objects once seized were returned and tourist trade was encouraged. Thus the Kwakiutl epic is one of the ambivalence of transnational power and the power of traditional cultural signs. While the Canadian authority remained, the Kwakiutl reenacted primordial myths and ceremonies, in this sense preserving their identity and culture and at the same time participating in the culture of the larger power.

It would not be possible to analyze all the signs prevalent in the so called totem pole and in all aspects of the art and politics and hierarchy and exchange where the giver is more powerful than the receiver, since this requires the full context of the Kwakiutl history, customs and beliefs which Wolf has tried to summarize from the immense literature of this tribe. Thus we must satisfy ourselves with a glimpse here.

The second case is the Aztecs, known for human sacrifice. This society dominated central Mexico from the 15th century until the Spanish conquest in 1521. In asking about the relation between ideas and power, Wolf discusses the relation of Aztec ideology and 
structural power. Here he focuses on social relations between producers of tribute and receivers of tribute (Wolf 1999: 124). The Aztecs, or more correctly the Tenochea, were a part of the Toltec domain which disintegrated after 1000. This group adopted a Toltec solar cult and sacrifice by heart incision (Wolf 1999: 137). As Tenochea gained power they claimed to be the Chosen People of the god Huitizlopochtli "who destined them for universal dominance" (Wolf 1999: 135). They became successful warriors. They believed that they should maintain the cosmos and they appropriated land labor and tribute from those they defeated (Wolf 1999: 141). They built temples and constructed a new society and calendar. Nobles wore special clothing, headdresses and ornaments. The chief ruler was in charge of the military and warriors were charged with the task of bringing back enemies to be sacrificed, which were associated with public rituals.

The cosmology and beliefs of the Aztec are too complex to be summarized here. Syncretic forms, Spanish and indigenous traditions, were intertwined. The Spanish destroyed the great temple, Tenochtitlan, all sacred texts and executed many of the priests. But memories of the past persisted, performances and festivals continued. And encouraged by the Mexican revolution of 1910, a florescence of the plastic and performative arts and "elements and themes drawn from was long thought of as a dead culture signal a live presence under new circumstances" (Wolf 1999: 195).

The third and final case is National Socialist Germany. The Third Reich lasted twelve years after its birth in 1997. To attempt to understand power and ideas in this case is more than ambitious. In close to 100 pages, Wolf attempts such an analysis (Wolf 1999: 197273) and I can only choose some high points here. Wolf sees an analogy of German National Socialism to cargo cults and ghost dances, although it is not like other revitalistic movements since it links vitality to apocalyptic visions of racial corruption (Wolf 1999: 198). While we cannot fully explain this movement, Wolf asks us to try. And he refers to various attempts that he believes are not mutually exclusive. Wolf is partial to the concept of "Sonderweb", which stresses the historical peculiarities of the development of the Germanies (Wolf 1999: 199). As a distinctive trajectory of German history (Wolf 1999: 198-199) reaching back to the 30 years war that ended in 1648 and earlier, demonstrate how ancient were the traditions that were 
mixed with populism, mass party organizations, capitalism etc. (Wolf 1999: 201).

Prussia became powerful after the 30 years war, and was the pivot of German unification. Thus after the defeat of France, Germans became strikingly more nationalistic and the German federation of loosely knit states became a movement towards self-cultivation, as opposed to nation building in France. The middle classes stressed training in the values of German Burgertum (pride of middle classes). Germans distinguished the Volks as part of nature as opposed to political and intellectual nations (Wolf 1999: 211). The dream was of a Reich Empire based on popular myths...

Prussia became stronger after the Treaty of Vienna (1915) when it was awarded new territory in West Germany and militarism was dominant. The defeat in WWI created greater hostility and deprivation. Volk and Geist were projected by the National Socialists to racial health, meaning eliminating undesirables: Jews, gypsies, misfits, etc.

Wolf concludes that National Socialism has not disappeared from the world. He writes that he finds it in new forms, in cries for regional autonomy and ethnic separatism. In the face of international finance and commerce and corporations, public policy is being challenged by demands for privatization including means of violence acquired by armed entrepreneurs linked up with mafia types.

The above can only be a sample of some of the main points of Wolf. The treatment of all these cases would require several lengthy articles and the German case would need still more.

This study concludes with a Coda (Wolf 1999: 274-291). While it summarizes and compares three cases, Wolf says they are incommensurate. He analyzes the kind of structural power that organizes each society but he brilliantly interweaves the role of imaginary worlds with his concept of power, and here on an abstract level these societies are commensurable. He unites the many different segmented approaches to culture and power with an overriding concept, that of imagination.

The following discussion from the Coda and my comments expands on the above conclusion. The three case studies were societies under maximum stress. In each case they developed an ideology fashioned out of preexisting cultural materials but power permeated the new agenda. Specifically, power organized and structured social labor "rooted in the nature of the cosmos" (Wolf 1999: 274). In 
Wolf's words "Old ideas were rephrased to fit different circumstances and new ideas were presented as age-old truths [...] [which] were resolved through the exercise of power" (Wolf 1999: 275).

The Kwakiutl society was stressed by contact with the modern powerful peoples who leveled various restrictions on the Kwakiutl and altered the economy. The Tenocha went from a local band to control of a regional empire. National Socialist Germany was preceded by a sudden unification, introduction of industrialism and dominance of a militaristic Prussia. And the loss of WWII ended National Socialist attempt at world conquest.

Turning to the cosmology of these three societies, they had in common that they sanctioned and underwrote the power of the elite. Kwakiutl cosmological rationale provided that chiefs reenact animal ancestors and hold special privileges. That required a redistribution which transferred vital powers to guests. Chiefs were initiated giving them the control of life and death issues between spirits and the living (Wolf 1999: 276). The advancing capitalism increased sources of wealth and epidemics, diminished the population including chiefly heirs, which led to an inflationary competition for privileges including the newly rich (Wolf 1999: 270).

The Tenocha economy was based on tribute paid by commoners to hereditary chiefs. Toward the end of the 15th century a military faction took over and revived mythological history supported by monumental art. The rulers considered that they had special power from the god of conquest and plunder and were responsible for sustaining time and the sun and offering human sacrifice to feed an ideology of world renewal.

In the first two cases discussed, the rulers had a special relation to plants and animals, and depended on rhetorical skills by which they projected the imagined worlds in which power holders had strategic power (Wolf 1999: 278).

Also in the case of National Socialist Germany, Wolf finds some analogies on the abstract level of power intertwined with cosmologies and imagined worlds. When Germany was dominated by the Prussians, the call was for a unified Volk which was further underwritten by the defeat in WWI. National Socialist ideology called for the rearmament of the national will and for building a war machine. While the Tenocha and the Kwakiutl saw human groups and plants and animals in constant struggle, the National Socialists devised 
the conception that human races had distinct origins, and history became a struggle in nature for the predominance of the superior Aryan race (Wolf 1999: 279). Ideological rhetoric extolled what we today call ethnic cleansing.

As from the point of view of history, and socio-economic type, these three societies are incommensurable, as I have noted, but in all three cases power depended on cosmological imperatives not limited to organizing society, but depending also "on relationships with imaginary elements and beings projected beyond tangible experience into metaphysical worlds" (Wolf 1999: 281).

Wolf calls our attention to the limitations of models of anthropologists explaining ideas and culture as for example functionalism, ecological factors, and structural and binary oppositions rooted in the biophysics of the mind. Helpful as these explanations are, the equally important area is what all this activity is about. What is the content of these practices?

Wolf is aware of Benveniste's (1971) insistence on the semantics of the sentence and the referent and thus context, for which he thought semiotics accounted (Wolf 1999: 282). But here something important is lacking since the Prague School's rebellion against Saussure was promulgated in the Theses of 1929. Accordingly the authors laid the basis for Prague school semiotics, which was led particularly by Mukařovsky, and was then taken up by the Tartu-Moscow school, particularly by Lotman who pioneered semiotics of culture.

When Wolf asks to what cultural signs point, or entail, what world is envisaged, who is setting up the valuation and for whom, and when he notes that some of the referents may be imaginary and many human beings and objects etc. may be ascribed imaginary power, here Wolf is in fact calling for a semiotics of culture (Wolf 1999: 282), a whole domain barely touched by American anthropologists. Wolf states: "the ideology of these three cases envision and project such imaginary worlds" (Wolf 1999: 283). Thus "the Kwakiutl assigned transhuman values to certain kinds of objects and made their distribution and exchange a major theme of their lives" (Wolf 1999: 283). The Tenocha imagined that the gods gave them life and had to be repaid by war and sacrifice The National Socialists thought they were carrying out the law of nature to preserve the Aryan race and destroy inferior types, and particularly the Jews. 
The persistence of sacred propositions, Wolf explains, is the power of ascribing to them transhuman forces giving their spokesmen "a special aura of authority and enhancing the efficacy of their words and ritual performance" (Wolf 1999: 285). Here Wolf suggests the pertinence of Austin's "perlocutionary" or "performative" speech acts producing perlocutionary performative truths (Wolf 1999: 285).

Wolf comments on the limitation of those who oppose enlightenment universal rational truths to the organic and spiritual whole culture, that is the invoking of ancient customs and folklore and tradition. Wolf argues for preserving the notion of culture in spite of all these conflicting views and ambiguities since culture accounts for human practices and discourses "covered neither by progressive universalism or by retrograde parochialism" (Wolf 1999: 287). As he argues, the human ability to construct figments in our mind, to think of metaphors and metonyms, is still not understood. Nor do we know how culture connects with power. Wolf advances the notion of structural power and its relation to ideology and imagination. He believes that the human capacity to envision imaginary worlds is beginning to elicit more interest as is also the question of how culture and power connect (Wolf 1999: 291).

I conclude with a message from Peirce with which Wolf's ideas interestingly resonate. As Peirce holds, the world is perfused with signs and all signs have three levels, one of which will be dominant, namely iconic, indexical and symbolic. Wolf has called our attention to the importance of Peirce's interpretant, which accounts for the infinite process of semiosis. The interpretant is not fixed but depends on the interpreter and thus the element of power communicated by the sign is variable. Like Jakobson's invisible oil that changes all the relationships of the ingredients of the salad, power is ubiquitous and transposing and thus is hard to be dealt with satisfactorily. Signs are what Jakobson called 'context sensitive' and their meanings will change depending on context, history, and the mindset of the senders and receivers. Their subliminal and disguised aspects are ever-present forces, but since forms of power are typically clothed and disguised in clichés, myths or what has been called double speak, such paradigms may be hard to detect, which helps to account for their frequent neglect. For power is embedded in signs, which must be interpreted.

Peirce's comments about imagination, although in this case referring to literature, are pertinent to Wolf's perception. He defines 
the real as "that whose characters are independent of what anybody may think" (CP 5.405), whereas the fictive [Peirce sometimes uses the term 'figment' instead of fiction] is the opposite of reality, namely

the product of somebody's imagination; it has such characters as his thought impresses upon it [...] [and is] independent of how you or I think [...] There are, however, phenomena within our own minds, dependent upon our thought, which are at the same time real in the sense that we really think them. But though their characters depend on how we think, they do not depend on what we think those characters to be. (CP 5.405)

I conclude that relevance is not the only criterion for important studies but in this case surely Wolf's power and imagination and ideology and Peirce's fictive worlds are important and relevant.

\section{References}

Benveniste, Émile 1971. Problems in General Linguistics. (Meek, Mary Elizabeth, trans.) Coral Gables: University of Miami Press.

Bourdieu, Pierre 1993. The Field of Cultural Production: Essays on Art and Literature. New York: Columbia University Press.

Dreyfus, Hubert L.; Rabinow, Paul (ed.) 1982. Michel Foucault: Beyond Structuralism and Hermeneutics. Chicago: University of Chicago Press.

Foucault, Michel 1983. Afterword by Michael Foucault: The subject and power. In: Dreyfus, Hubert L.; Rabinow, Paul (ed.), Michel Foucault: Beyond Structuralism and Hermeneutics. 2nd edition. Chicago: University of Chicago Press, 208-228.

Jakobson, Roman; Tynjanov, Jurij 1972 [1928]. Problems in the study of language and literature. (De George, Richard T., trans.) In: De George, Richard T.; De George, Fernande M. (eds.), The Structuralists: From Marx to Lévi-Strauss. New York: Anchor, 81-83. [Original in: Novyj LEF 12: 36-37.]

Peirce, Charles Sanders 1931-1958. Collected Papers, vols. 1-6 (Hartshorne, C.; Weiss, P., eds.); vols. 7-8 (Burks, A. W., ed.). Cambridge: Harvard University Press. [Cited as CP.]

Portis-Winner, Irene 2002a. Eric Wolf: the crosser of boundaries. Sign Systems Studies 30(2): 465-484.

- 2002b. Semiotics of Peasants in Transition: Slovene Villagers and Their Ethnic Relatives in America. Durham: Duke University Press.

Voloshinov, Valentin N. 1986. Marxism and the Philosophy of Language. Cambridge: Harvard University Press.

Wolf, Eric R.1959. Sons of the Shaking Earth. Chicago: University of Chicago Press.

- 1964. Anthropology. Prentice-Hall: Englewood Cliffs. 
- 1964. Santa Claus: Notes on a collective representation. In: Manners, Robert A. (ed.), Process and Pattern in Culture. Chicago: Aldine, 147-155.

- 1982. Europe and the People Without History. Berkeley: University of California Press.

- 1999. Envisioning Power: Ideologies of Dominance and Crisis. Berkeley: University of California Press.

- 2001. Pathways of Power: Building an Anthropology of the Modern World. Berkeley: University of California Press. [With Sydel Silverman]

\section{Эрик Вольф: семиотическое изучение власти}

Рассматривается анализ власти в последней книге Эрика Вольфа Envisioning Power (1999). В своей короткой книге под названием «Антропология» Вольф пишет, что «антропологическая исходная точка - это постоянно образующаяся мировая культура». Т.е. нужно изучать людской опыт во всей ее изменчивости и сложности. Его целью была создать обрамление, соединяющее гуманитарные науки и антропологию. Свой проект он не закончил, а только расширял. В новом введении к его книге 1964 года, 30 лет спустя, он пришел к выводу, что ожидаемый синтез не состоялся, а скорее наоборот - выросли новые преграды. В предисловии к Envisioning Power он полагает, что гуманитарные науки были неспособны или не имели желания принять к сведению тот факт, что культурные конфигурации тесно переплетены с силами власти. В 1990 году он написал Американскому антропологическому обществу, что антропологи предпочитают рассматривать культуру безотносительно к власти, в то время как другие социальные науки выдвигают понятие идеологии без культуры. Он написал, что цель его последней книги разъяснить связь идей и власти, основываясь на поведении и записанных текстах. В то время как разум выдвигает разделяющий экран между организмом и его окружением, идеи имеют содержание и функции, помогающие объединять или разделять людей. Несмотря на то, что идеи составляют суть ментальных конструкций, Вольф понимает идеологию как конфигурацию унифицированных схем, обеспечивающих или манифестирующих власть. Власть есть по Вольфу аспект всех межчеловеческих взаимоотношений. Внутри такого теоретического обрамления Вольф изучает 3 разных случая: Kwakiutl, ацтеков и нацистской Германии. Сравнения хорошо показывают как различия так и сходство в конфигурациях власти и в роли воображения. 


\section{Eric Wolf: semiootiline uurimus võimust}

Vaatluse all on võimu analüüs Eric Wolfi viimases monograafias Envisioning Power (1999). Oma lühiteoses pealkirjaga "Antropoloogia" kirjutab Wolf, et "antropoloogia vaateplatvormiks on hetkel sündimasolev maailmakultuur" (1964: 96). Oluliseks uurimisobjektiks on just inimkogemus kogu tema mitmekesisuses ja muutlikkuses. Wolfi eesmärgiks oli luua humanitaarteaduseid ja antropoloogiat ühendav raamistik. Seda püüdlust ei hüljanud ta kunagi, vaid arendas pidevalt edasi. Oma uues sissejuhatuses 1964. aastal kirjutatud raamatule 30 aastat hiljem jõuab ta järeldusele, et oodatud süntees ei leidnud aset, vaid hoopis vastupidi ühinemise teele kasvasid uued tõkked. Eessõnas raamatule Envisioning Power väidab ta, et humanitaarteadused ei ole olnud võimelised või siis ei ole soovinud mõista seda, kuidas kultuurilised konfiguratsioonid põimuvad võimukaalutlustega. 1990. aastal pidas Wolf Ameerika Antropoloogia Seltsis kõne, milles väitis, et antropoloogid eelistavad vaadelda kultuuri võimust eraldi, samal ajal kui teised sotsiaalteadused tõstavad kilbile kultuurist lahutatud ideoloogia mõiste. Ta kirjutas, et tema viimase raamatu eesmärgiks on selgitada ideede ja võimu vahelisi seoseid, tuginedes käitumispraktikatele ja kirjalikele tekstidele. Kuna mõistus tekitab organismi ja teda ümbritseva keskkonna vahele eraldusloori, on ideedel sisu ja funktsioonid, mis aitavad inimesi lahutada või ühte siduda. Kui ideed on Wolfi jaoks mentaalsete konstruktsioonide põhisisuks, siis ideoloogiat mõistab Wolf kui võimu toimimiseks või näitamiseks vajalikke malle või ühtlustatud skeeme. Võim on Wolfi järgi kõikide inimestevaheliste suhete üks aspekt. Taolise teoreetilise raamistiku sees vaatleb Wolf kolme erinevat juhtumit: kwakiutlid, asteegid ja natslik Saksamaa. Võrdluses on hästi näha nii sarnasus kui erinevus võimu konfiguratsioonides ja ettekujutuse rollis. 